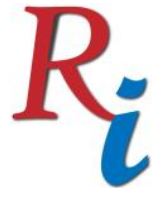

Asia Proceedings of Social Sciences

(APSS)

www.readersinsight.net/APSS

\title{
Exotic Diseases: Challenges to Leveraging Compensation Rights based on Infections
}

\author{
Marziah Zahar* \\ Department of Human Resource Management, School of Business Management (SBM), College of Business, \\ Universiti Utara Malaysia \\ Malaysia
}

*Corrosponding author's Email: marziah@uum.edu.my

Peer-review under responsibility of $4^{\text {th }}$ Asia International Conference 2018 editorial board

(http://www.utm.my/asia/our-team/)

(C) 2018 Published by Readers Insight Publisher,

lat 306 Savoy Residencia, Block 3 F11/1,44000 Islamabad. Pakistan,

info@ readersinsight.net

This is an open access article under the CC BY-NC-ND license (http://creativecommons.org/licenses/by-nc-nd/4.0/). 


\section{Research High Iight s}

Malaysia is a tropical terrain that opposes some of unique, exotic diseases such as; Dengue, Rabies, Leptospirosis, Chikungunya, H1N1, SARS, AIDS, and Japanese Encephalitis. In this review, we elaborate a possible correlation of the above diseases in the occupational environments. Until today, debates on providing compensation based on microbe infection still continue. As the exotic cases continue to rise globally, we continue to re-raise awareness to improve the chances of considerate compensation based on work-related infection diseases.

\section{Research Objectives}

Humans are vulnerable to ordinary disease of life, in which usually occurs via microbial infections and outside the scope of employment. The severity of the infection depends on human immune condition. To be covered under Malaysia Employee Social Security Act, sick employees must demonstrate that their current illness results directly from conditions of their employment, and such exposure is in excess of those found in the general public. This creates an interesting scenario for employers in the medical profession. Doctors, nurses, and other medical professionals globally are certainly at risk of exposure to the "ordinary diseases of life.". Apart from the medical profession, infection in the workplace may occur in people who work as farmers, abbatoir, army, forest ranger, sewer worker etc.

The objective of this review investigate trends of exotic diseases in Malaysia and creating awareness of microbial infection in occupational disease in Malaysian's perspective.

\section{Methodology}

In this review, we are focusing on the process of microbial invasion inside the host based on open wounds transmission. Next, we correlate its connections with several papers that reviewed trends of microbial infection in occupational disease on the tropical climate. In 


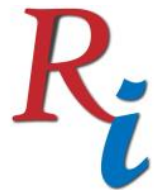

\section{Asia Proceedings of Social Sciences \\ (APSS) \\ www.readersinsight.net/APSS}

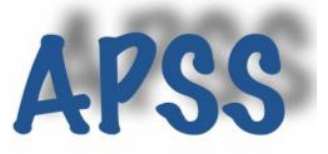

addition, we investigate a real chronology case that deals with compensation rejection, which beliefs related to viral infections.

\section{Findings}

A microbacterium has existed on the earth for billions of years. Numerous amounts of its species were a dynamic key player in the natural ecological system by regulating biogeochemical cycle for its sustainability (Danovaro et al., 2017). Therefore, a microbacterium has certain ability to survive in a normal or a thriving environment. For instance, several microbes were successfully cultivated from a high pressure, salinity, temperature, concentration, and vice versa (Marziah et al., 2016).

An occupational injury is usually determined by a mechanical trauma; an injury to any portion in a body that is visible to the naked eyes such as; a blow, crush, cut, or penetrating wound. Many infections are associated with occupations. If an individual, without his / her knowing having an immunocompromised condition, it may get worse if he/she were exposed to an open wound - A perfect entry route for the microbial agent. Specific occupation with high-risk of mechanical injury, working culture, and unique working environment may induces a high risk of unique infections (Haagsama et al., 2012), I.e Healthcare workers, workers in contact with animals, laboratory workers, miner, farmer, sewage worker seem to have the highest risk of infection by a variety of pathogens.

However, all current findings need a better qualitative reporting such as a systematic review of work-related infectious disease in a matrix of the occupational group and arranging an exposure pathway that allows reliable identification of exposure hazard for specific occupational group beyond currently reported diseases (Haagsma et al, 2012). Therefore, it is important for all occupational infections to be diagnosed as adequate preventive measures need to be implemented. Furthermore, the patient may be eligible for monetary compensation under the relevant occupational safety laws of the country (Lim, 2009).

In the perspective of the law, the Claimant's attorneys always remind its client that not all diseases are ordinary diseases of life. Some diseases are instead, occupational diseases and have a substantial connection to the employment. Therefore it should not regard as the ordinary disease of life (Texas Defence Council, 2014). 
www.readersinsight.net/APSS

\section{References}

Danovaro, R., Zoologica, S., Dohrn, A., \& Gambi, C. (2017). A submarine volcanic eruption leads to a novel microbial habitat, (June). https://doi.org/10.1038/s41559-0170144

Haagsma, J. A., Tariq, L., Heederik, D. J., \& Havelaar, A. H. (2012). Infectious disease risks associated with occupational exposure: a systematic review of the literature. Occupational and Environmental Medicine, 69(2), 140 LP-146. Retrieved from http://oem.bmj.com/content/69/2/140.abstract

Lim, V. K. E. (2009). Occupational infections. The Malaysian Journal of Pathology, 31(1), 1-9. Retrieved from http://www.ncbi.nlm.nih.gov/pubmed/23283035

Marziah, Z., Mahdzir, A., Musa, M. N., Jaafar, A. B., Azhim, A., \& Hara, H. (2016). Abundance of sulfur-degrading bacteria in a benthic bacterial community of shallow sea sediment in the off-Terengganu coast of the South China Sea. MicrobiologyOpen, 5(6), 967-978. https://doi.org/doi:10.1002/mbo3.380

Pei, W., Tanaka, K., Huang, S. C., Xu, L., Liu, B., Sinclair, J., ... Burgess, S. M. (2016). Extracellular HSP60 triggers tissue regeneration and wound healing by regulating inflammation and cell proliferation. Npj Regenerative Medicine, 1, 16013. Retrieved from https://doi.org/10.1038/npjregenmed.2016.13

Texas Defence Counsel. (2014). Occupational Disease or Ordinary Disease of Life?-Fort Worth, Texas Workers' Compensation Attorneys. Retrieved February 24, 2014, from http://www.texasdefensecounsel.com/occupational-disease-orordinary-disease-of-life 